\title{
Vitamin D status in a rural population of northern Norway with high fish liver consumption
}

\author{
M Brustad ${ }^{1, *}$, T Sandanger $^{2}$, L Aksnes $^{3}$ and E Lund ${ }^{1}$ \\ ${ }^{1}$ Institute of Community Medicine, University of Tromsø, N-9037 Tromsø, Norway: ${ }^{2}$ Norwegian Institute for Air \\ Research, Polar Environmental Centre, Tromsø, Norway: ${ }^{3}$ Department of Paediatrics, University of Bergen, Norway
}

Submitted 23 0ctober 2003: Accepted 17 January 2004

\begin{abstract}
Objective: To assess vitamin D status and the impact of three fish meals consisting of cod liver and fresh cod-liver oil on the plasma level of vitamin D metabolites in an area with high consumption of cod liver and cod-liver oil.

Design: Experimental field study.

Methods: Thirty-two volunteers from the Skjervøy $\left(70^{\circ} \mathrm{N}\right)$ municipality in northern Norway were recruited to consume three traditional mølje meals, consisting of cod, cod liver, fresh cod-liver oil and hard roe, in one week. The liver and fresh cod-liver oil consumed by the participants were weighed and recorded. Blood samples were collected before the first meal, and subsequently $12 \mathrm{~h}$ and 4 days after the last meal. The blood samples were analysed for the vitamin D metabolites 25-hydroxyvitamin D $(25(\mathrm{OH}) \mathrm{D})$ and 1,25-dihydroxyvitamin $\mathrm{D}\left(1,25(\mathrm{OH})_{2} \mathrm{D}\right)$. All participants answered a semi-quantitative food-frequency questionnaire, which was used to estimate usual daily nutrient intake. The study was carried out in the last part of March 2001.

Results: The median daily vitamin D intake estimated from the questionnaire was $9.9 \mu \mathrm{g}$. The proportion of subjects with baseline $25(\mathrm{OH}) \mathrm{D}$ level below $50 \mathrm{nmoll}^{-1}$ was $15.4 \%$ and none were below $37.5 \mathrm{nmol}^{-1}$. Only 'mølje consumption' and 'time spent in daylight' were significantly associated with baseline $\log 25(\mathrm{OH}) \mathrm{D}$. The mean total intake of vitamin D in the three servings was $272 \mu \mathrm{g}$ (standard deviation $94 \mu \mathrm{g}$ ), ranging from 142 to $434 \mu \mathrm{g}$. Relative to baseline plasma concentration, the mean level of $25(\mathrm{OH}) \mathrm{D}$ decreased slightly in both post-consumption samples $(P \leq 0.03)$, while $1,25(\mathrm{OH})_{2} \mathrm{D}$ peaked $12 \mathrm{~h}$ after the final meal $(P=0.03)$.

Conclusion: Three mølje meals provided, on average, an amount of vitamin $\mathrm{D}$ equal to 54 times the recommended daily dose. Subjects with food consumption habits that included frequent mølje meals during the winter sustained satisfactory vitamin D levels in their blood, in spite of the long 'vitamin D winter' (i.e. absence of ultravioletinduced vitamin D production in the skin).
\end{abstract}

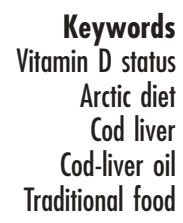

Dietary sources of vitamin D are scarce. It is found mainly in fatty fish, cod-liver oil and fortified margarine or butter. Ultraviolet (UV)-induced skin production constitutes the main contributor to vitamin $\mathrm{D}$ in humans. UV radiation with wavelengths less than $320 \mathrm{~nm}$ is needed for this cutaneous photoconversion of provitamin D (7-dehydrocholesterol) to previtamin $\mathrm{D}$, which is the precursor to vitamin $\mathrm{D}^{1}$. The great seasonal variation in UV levels has been found to cause seasonal fluctuations in the vitamin D status of humans ${ }^{2}$. Fish liver has traditionally been the most important vitamin D source for the coastal population of northern Norway during the winter months ${ }^{3}$, since at these latitudes the sun-induced vitamin $\mathrm{D}$ production ceases for a considerable part of the year. The fish liver consumed was mainly from cod (Gadus morbua L.) and saithe (Pollachius virens), and the primary consumption followed the seasonal harvests. The cod liver season was linked to the spawning period and lasted about three months during the winter (most usually from January until March/April). Saithe liver was consumed from late summer until September/October.

A recent epidemiological investigation has confirmed the importance of diet to vitamin D status in the population of northern Norway ${ }^{4}$. Unpublished data from the nationwide Norwegian Women and Cancer Study (NOWAC $)^{5}$ have shown that there are still communities where fish liver and fresh fish-liver oil are consumed frequently. The coastal municipality of Skjervøy, which is situated at $70^{\circ} \mathrm{N}$, was identified as one of those with the highest frequency of consumption. Fifty per cent of the participating subjects reported eating fish liver and fishliver oil - or mølje, which is the Norwegian name of the 
dish - seven times per season or more. In a recent study among volunteers in Troms $\varnothing^{6}$, the largest city in northern Norway, it was found that the average vitamin D consumption from one single fish meal containing fish liver and fresh cod-liver oil was $73.3 \mu \mathrm{g}$, which is about 15 times the recommended daily intake $(5.0 \mu \mathrm{g})^{7}$. According to the unpublished NOWAC data, mølje consumption seems to be more common in the rural coastal northern areas than among the more urban centres.

Among the metabolites for determining the overall vitamin $\mathrm{D}$ status of an individual, 25-hydroxyvitamin D (25(OH)D) has been used most often ${ }^{8}$. Blood 25(OH)D concentration $\leq 37.5 \mathrm{nmoll}^{-1}$ has been designated as an indicator of moderate hypovitaminosis $\mathrm{D}^{9,10}$ and concentrations $\geq 50 \mathrm{nmoll}^{-1}$ have been recommended ${ }^{11,12}$. The metabolite 1,25 -dihydroxyvitamin $\mathrm{D}\left(1,25(\mathrm{OH})_{2} \mathrm{D}\right)$ is the biologically active form ${ }^{1}$.

We recruited volunteers from the rural costal village of Skjervøy with the aim of assessing the impact of the traditional fish dish mølje, containing fish liver and fishliver oil, on plasma levels of vitamin D and its metabolites in a population with high mølje consumption. We studied the effect of three consecutive fish meals on these parameters.

\section{Methods and materials}

Study subjects were recruited by announcement in the local newspaper. Inclusion criteria were either gender, above the age of 20 years and living in the municipality of Skjervøy. Thirty-two volunteers, 21 men and 11 women aged 38-61 years, wanted to take part in the study. The project was approved by the Regional Committee for Research Ethics, and all subjects signed a consent form.

The study schedule is outlined in Fig. 1. All participants answered the NOWAC food-frequency questionnaire (FFQ), which was used to estimate usual daily nutrient intakes. This questionnaire has been described in detail elsewhere ${ }^{5,13}$. A slight alteration of the questionnaire was made to allow discrimination between cod liver and saithe liver consumption and the recoding of usual consumption patterns. In addition we included questions on hours spent in daylight the previous week, as well as sunseeking holidays and use of a solarium during the month prior to the study. The questionnaire also contained questions on gender, age, height and weight of the respondents.
The subjects were served three mølje meals with a 2-day interval during a 7-day period. All meals were served in the canteen at Skjervøy Upper Secondary School. The mølje meals were prepared in the traditional way by students attending the hotel and food-processing courses at this school. The fish was caught the day before or the same day it was served. Both the cod and the hard roe were boiled separately in water. The liver was divided and boiled in only small amounts of water and the oil derived from this constituted the fresh cod-liver oil. Participants served themselves and took as much as he or she wanted at the arranged fish buffet, but the amounts of liver and cod-liver oil on each participant's plate were weighed using digital scales and the weights recorded in grams by trained students at the school.

Blood samples were collected from participants before the first meal, and $12 \mathrm{~h}$ and 4 days after the last meal. The blood samples were collected into vacutainer tubes containing ethylenediaminetetraacetic acid $(9 \mathrm{ml}$ lavender top; Becton-Dickinson, Plymouth, UK). Participants' body weight and height were measured on day 8 or day 11 . The study was carried out in the last part of March 2001. Participants were asked to maintain their usual diet during the study period.

Usual (i.e. self-reported) daily vitamin D intake was computed using information from the FFQ and the corresponding nutrient values reported in the Norwegian Food Composition Table ${ }^{14}$, as well as our food analysis of liver and fresh cod-liver oil as described below. Owing to limited information on the nutrient content of different supplements, vitamin D contributions from dietary supplements other than cod-liver oil were not included in estimating the usual daily vitamin D intake for each participant.

\section{Food sample analyses}

Samples from the liver and fresh cod-liver oil servings were analysed for vitamin D according to the method described by Horvli and $\mathrm{Lie}^{15}$. In short, vitamin $\mathrm{D}$ was extracted using 96\% ethanol/37.5\% KOH (15:1 v/v), containing pyrogallol, ascorbic acid and an internal standard (vitamin $\mathrm{D}_{2}$ ). Heating to $70^{\circ} \mathrm{C}$ for $20 \mathrm{~min}$ saponified the sample. After the addition of water, the sample was extracted twice with hexane using a whirlmixer and a centrifuge. The combined hexane phases were extracted with water, and isopropanol was added before evaporation. The sample was cleaned up further

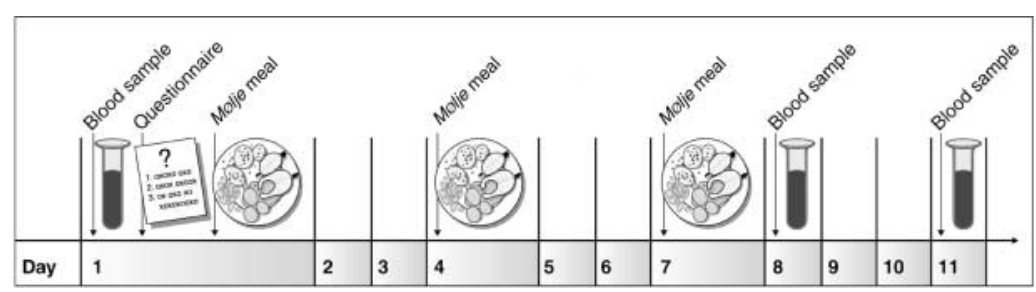

Fig. 1 Study design and blood sampling schedule (blood samples were collected before meal 1, and 12h and 4 days after meal 3 ) 
using a high-performance liquid chromatography (HPLC) system consisting of a Spectra Physics P1000 isocratic pump, a Shimadzu SPD 6AV UV detector and a Shimadzu C-3A integrator, fitted with a Brownlee silica column $(25 \mathrm{~cm} \times 4.6 \mathrm{~mm}, 5 \mu \mathrm{m})$. For the analytical step, a $\mathrm{C}_{18}$ column $(25 \mathrm{~cm} \times 4.6 \mathrm{~mm}, 5 \mu \mathrm{m}$; Supelco Inc., Bellefonte, USA) was used.

For the preparative clean-up step, tetrahydrofuran-nhexane (12.5:87.5 v/v) was used as the mobile phase. For the analytical step, chloroform-methanol-acetonitrile $(6: 12: 82 \mathrm{v} / \mathrm{v})$ was employed as eluent and the sample was dissolved in methanol. The flow rates were $1 \mathrm{ml} \mathrm{min}^{-1}$ for both columns. Vitamin $\mathrm{D}_{2}$ (internal standard) and $\mathrm{D}_{3}$ were detected on-line by the UV detector at $265 \mathrm{~nm}$. These analyses were carried out by the Directorate of Fisheries, Institute of Nutrition, Bergen, Norway.

The vitamin D intake from the mølje meal was estimated on the basis of the vitamin D content of the liver and fresh cod-liver oil served, since the rest of the food items consumed (cod, potatoes and hard roe) contain little or no vitamin D.

\section{Plasma levels of 25(OH)D and 1,25( $\mathrm{OH})_{2} \mathrm{D}$}

Blood plasma was collected and kept at $-80^{\circ} \mathrm{C}$ until analysed for $25(\mathrm{OH}) \mathrm{D}$ and $1,25(\mathrm{OH})_{2} \mathrm{D}$ according to modified versions of the methods described by Aksnes ${ }^{16,17}$. Briefly, $1.5 \mathrm{ml}$ plasma samples were mixed with $2 \mathrm{ml}$ of acetonitrile, vortexed and centrifuged at $1000 \mathrm{~g}$ for $10 \mathrm{~min}$ to remove proteins. The supernatants were collected, $3.5 \mathrm{ml}$ of $0.1 \mathrm{M} \mathrm{K}_{2} \mathrm{HPO}_{4}(\mathrm{pH} 10.5)$ was added, and the mixture applied to $\mathrm{C}-18-\mathrm{OH}$ vacuum columns (Varian, USA). The columns were washed with $5 \mathrm{ml}$ of distilled water, followed by a second wash with $5 \mathrm{ml}$ of methanol-water $(70: 30 \mathrm{v} / \mathrm{v})$, after which the $25(\mathrm{OH}) \mathrm{D}$ and $1,25(\mathrm{OH})_{2} \mathrm{D}$ fractions were eluted with hexane-isopropanol $(95: 5 \mathrm{v} / \mathrm{v})$ and evaporated to dryness with a gentle flow of nitrogen. The samples were dissolved in $250 \mu$ l of hexane-isopropanol-ethanol (95:2.5:2.5 v/v) and the collected fraction was separated on a silica column (Supelcosil, $15 \mathrm{~cm} \times 4.6 \mathrm{~mm}, 3 \mu \mathrm{m}$; Supelco Inc.) by HPLC. The fractions containing $25(\mathrm{OH}) \mathrm{D}$ and $1,25(\mathrm{OH})_{2} \mathrm{D}$ were collected, again evaporated to dryness with nitrogen gas, and then dissolved in ethanol. 25(OH)D was quantified by a radioreceptor assay (RRA) using human vitamin D binding protein from blood plasma as the binding protein, and $1,25(\mathrm{OH})_{2} \mathrm{D}$ by an RRA using the $1,25(\mathrm{OH})_{2} \mathrm{D}$ receptor from chick duodenal cytosol.

\section{Serum paratbyroid bormone}

Serum parathyroid hormone (PTH) levels were measured with an Immulite analyser (Diagnostic Products, Los Angeles, CA, USA) on the basis of a two-site chemiluminescent immunometric assay. The Immulite analyser has a working range of $0.1-263 \mathrm{pmol}^{-1}$.

\section{Statistical analyses}

Statistical analyses and nutrient calculations were done with the SAS software package, version 8.02 (SAS Institute, Cary, NC, USA). Log-transformed values for the variable $25(\mathrm{OH}) \mathrm{D}$ were used in the general linear models and $t$ tests because this variable was not normally distributed. When general linear models were chosen, a test for colinearity (variance of inflation factor) between the independent variables was applied. Independent variables were selected by backward elimination. For the analysis of baseline 25(OH)D levels, the subjects who reported that they had been on sun holiday or had recently used a solarium were excluded $(n=4)$ in addition to subjects for whom this information was missing $(n=2)$. Cod-liver oil supplement use was defined as taking it more than twice per week. Pearson correlation coefficients were calculated for the self-reported daily intakes of vitamin D and the $25(\mathrm{OH}) \mathrm{D}$ concentrations in blood at baseline. Paired sample $t$-tests and analysis of variance (ANOVA) with repeated measures design were used to compare changes in vitamin D metabolite levels with time.

\section{Results}

Some characteristics of the participants are shown in Table 1. The median self-reported usual vitamin D intake estimated from the semi-quantitative FFQ was $9.9 \mu \mathrm{gday}^{-1}$. According to the questionnaire data, $47 \%$ of the participants ate mølje two to three times per month or more, and $17 \%$ did so once per week or more during the mølje season (Fig. 2).

Table 1 Characteristics of the study sample $(n=32)^{\star}$. Values are expressed as median or \%

\begin{tabular}{|c|c|c|c|c|}
\hline Characteristic & Men $(n=21)$ & Women $(n=11)$ & Total & Range \\
\hline Age (years) & 52 & 50 & 50 & $38-61$ \\
\hline Body mass index $\left(\mathrm{kg} \mathrm{m}^{-2}\right)$ & 29.4 & 28.3 & 29.2 & $19.8-35.6$ \\
\hline $\begin{array}{l}\text { Usual vitamin D intake }\left(\mu g \text { day }^{-1}\right) \\
\quad \text { (supplements other than cod-liver oil excluded) }\end{array}$ & 11.5 & 5.9 & 9.9 & $3.0-40.1$ \\
\hline $\begin{array}{l}\text { Proportion of subjects reporting taking cod-liver } \\
\text { oil supplements twice per week or more }(\%)\end{array}$ & 52.4 & 27.3 & 43.8 & \\
\hline $\begin{array}{l}\text { Proportion of subjects who had been on a sun holiday } \\
\text { or used a solarium the month prior to the study (\%) }\end{array}$ & 10.0 & 20.0 & 13.3 & \\
\hline
\end{tabular}

* Subgroups may not total to 32 due to missing values. 


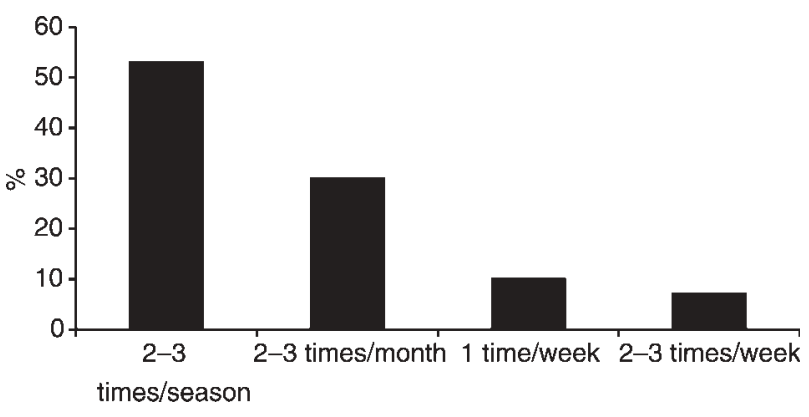

Fig. 2 Frequency of consumption during the mølje season (a season is estimated as about three months) among the study participants $(n=30)$

\section{The mølje meals served}

The median intakes in grams of cod liver and fresh codliver oil consumed during the three meals are shown in Table 2, as well as the total percentage of fat and the amount of vitamin D per $100 \mathrm{~g}$ of food served per meal. The vitamin D content per $100 \mathrm{~g}$ of food varied two-fold between meals, while the fat content was approximately constant. As illustrated in Table 3, the total vitamin D intake from the served meals was higher only for men compared with women $(P=0.004)$ and not for any of the other parameters listed. The mean total quantity of vitamin $\mathrm{D}$ provided in the three meals was $271.9 \mu \mathrm{g}$ (standard deviation (SD) $93.9 \mu \mathrm{g}$ ), ranging from 142.4 to $434.4 \mu \mathrm{g}$; the median intake was $264.1 \mu \mathrm{g}$.

\section{Baseline 25(OH)D}

The distribution pattern observed in the baseline concentrations of $25(\mathrm{OH}) \mathrm{D}$ is depicted in Fig. 3, corresponding to a mean concentration of $67.2 \mathrm{nmoll}^{-1}$. The proportion of subjects with $25(\mathrm{OH}) \mathrm{D}$ levels below $50 \mathrm{nmoll}^{-1}$ was $15.4 \%$ and none were below $37.5 \mathrm{nmoll}^{-1}$. In the unadjusted analysis (Table 3), codliver oil supplement users had significantly higher $25(\mathrm{OH}) \mathrm{D}$ levels in their blood $(P=0.04)$ compared with non-users. Furthermore, subjects who spent $<7 \mathrm{~h}$ per week in daylight the week prior to the study had significantly lower $25(\mathrm{OH}) \mathrm{D}$ concentrations in their blood compared with those who spent more time in daylight $(P=0.02)$. There was a significant trend $(P=0.04)$ in baseline $25(\mathrm{OH}) \mathrm{D}$ concentration by frequency of recalled mølje consumption. The proportion of subjects with

Table 2 Median total intake of cod liver and cod-liver oil from the three served molje meals and the calculated nutrient content

\begin{tabular}{lccc}
\hline Food item & Median intake $(\mathrm{g})$ & Vitamin D $(\mu \mathrm{g} / 100 \mathrm{~g})$ & Total fat $(\%)$ \\
\hline $\begin{array}{l}\text { Cod liver } \\
\text { Meal 1 }\end{array}$ & 108 & 50 & \\
Meal 2 & 115 & 40 & 48.6 \\
Meal 3 & 95 & 80 & 50.9 \\
Cod-liver oil & & & 44.7 \\
Meal 1 & 28 & 90 & \\
Meal 2 & 25 & 60 & 96.2 \\
Meal 3 & 25 & 120 & 96.4 \\
\hline
\end{tabular}

baseline $25(\mathrm{OH}) \mathrm{D}$ levels below $50 \mathrm{nmoll}^{-1}$ decreased with increased frequency of recalled mølje consumption.

The correlation coefficient for intake of vitamin $D$ and levels in blood was $r=0.30$, but not significant $(P=0.13)$. Subjects with a self-reported daily intake of vitamin D less than $10 \mu \mathrm{g}$ had on average a $25(\mathrm{OH}) \mathrm{D}$ concentration of 62.4 (SD 13.4) $\mathrm{nmoll}^{-1}$ at baseline, compared with subjects having a daily intake of $10 \mu \mathrm{g}$ or more, for whom it was 70.6 (SD 18.7) $\mathrm{nmoll}^{-1}$ (Table 3). However, this difference was not significant. In the multiple regression model only 'mølje consumption' and 'time spent in daylight' were significantly associated with $\log 25(\mathrm{OH}) \mathrm{D}$, adjusted for age and gender, while body mass index (BMI) had no effect as a predictor of vitamin D status at baseline (Table 4).

\section{Changes in vitamin $D$ metabolites and PTH associated with mølje meals}

There was a slight decrease in $25(\mathrm{OH}) \mathrm{D}$ levels at $12 \mathrm{~h}$ $(P=0.03)$ and 4 days $(P=0.004)$ after the last meal (Fig. 4). In the ANOVA for repeated measures design, there was a significant time effect for $\log 25(\mathrm{OH}) \mathrm{D}(P=0.001)$ and for $1,25(\mathrm{OH})_{2} \mathrm{D}(P=0.05)$. Compared with baseline, there was an increase in $1,25(\mathrm{OH})_{2} \mathrm{D}$ levels at $12 \mathrm{~h}(P=0.03)$ after the third serving, but not after 4 days. The changes over time in $25(\mathrm{OH}) \mathrm{D}$ and $1,25(\mathrm{OH})_{2} \mathrm{D}$ levels were not significantly associated with the total vitamin D consumed in the three served meals, nor with any of the following variables: gender, age, BMI, time spent in daylight, codliver oil supplement use, frequency of mølje consumption, and self-reported daily intake of vitamin D (ANOVA for repeated measurements, data not shown). The mean PTH serum concentrations ( $\mathrm{pmol}^{-1}$ ) were 5.0 (SD 2.3), 5.4 (SD 2.9) and 3.8 (SD 1.7) at baseline, $12 \mathrm{~h}$ and 4 days after the last meal, respectively. The slight rise in PTH between baseline and $12 \mathrm{~h}$ after the last meal was non-significant, while the decrease at 4 days relative to baseline was highly significant $(P<0.001)$ when adjusting for age and sex.

\section{Discussion}

We found that the three consecutive mølje meals gave a short-term increase in plasma concentration of the active vitamin D metabolite $1,25(\mathrm{OH})_{2} \mathrm{D}$ and a slight decrease in circulating 25(OH)D levels. However, baseline vitamin D status measured as $25(\mathrm{OH}) \mathrm{D}$ concentration was explained by both time spent in daylight the week before the study and frequency of self-reported mølje consumption. Furthermore, among these subjects from Skjervøy, $25(\mathrm{OH}) \mathrm{D}$ levels were relatively high and very few subjects had $25(\mathrm{OH}) \mathrm{D}$ below the recommended level.

In the beginning of April 2000, we conducted a similar study in the city of Troms $\varnothing$, northern Norway $\left(69^{\circ} \mathrm{N}\right)$, in which 33 volunteers were served a single mølje meal followed by repeated blood measurements of vitamin $\mathrm{D}^{6}$. Around $75 \%$ of these subjects had baseline concentrations 
Table 3 Plasma 25(OH)D levels at baseline and intake of vitamin D through the served mølje meals, by different characteristics* Values are expressed as mean (SD) or \%

\begin{tabular}{|c|c|c|c|}
\hline Characteristic & $\begin{array}{l}\text { Baseline } 25(\mathrm{OH}) \mathrm{D} \\
\left(\mathrm{nmoll}^{-1}\right) \dagger \ddagger\end{array}$ & $\begin{array}{c}\text { Proportion with } \\
\text { baseline } 25(\mathrm{OH}) \mathrm{D} \\
\text { level }<50 \mathrm{nmolI}^{-1}(\%) \dagger\end{array}$ & $\begin{array}{l}\text { Vitamin D consumed } \\
(\mu \mathrm{g}) \text { through the } \\
\text { mølje meals } \ddagger\end{array}$ \\
\hline Total & $67.2(16.9)$ & 15.4 & $272(94)$ \\
\hline \multicolumn{4}{|l|}{ Age (years) } \\
\hline$<50(n=14)$ & $66.8(16.5)$ & 21.4 & $284(104)$ \\
\hline \multirow{2}{*}{$\geq 50(n=18)$} & $67.2(17.8)$ & 11.1 & $262(87)$ \\
\hline & $P=0.92$ & & $P=0.52$ \\
\hline \multicolumn{4}{|l|}{ Gender } \\
\hline Men $(n=21)$ & $68.6(11.4)$ & 9.5 & 305 (107) \\
\hline Women $(n=11)$ & $63.9(13.4)$ & 27.3 & $209(75)$ \\
\hline & $P=0.53$ & & $P=0.004$ \\
\hline \multicolumn{4}{|l|}{ BMI $\left(\mathrm{kg} \mathrm{m}^{-2}\right)$} \\
\hline$<25(n=9)$ & $67.4(14.3)$ & 0.0 & $239(100)$ \\
\hline \multirow{2}{*}{$\geq 25(n=23)$} & $67.1(17.9)$ & 20.0 & $285(90)$ \\
\hline & $P=0.97$ & & $P=0.22$ \\
\hline \multicolumn{4}{|l|}{ Cod-liver oil supplement use } \\
\hline Yes $(n=14)$ & $73.8(18.6)$ & 7.1 & $260(76)$ \\
\hline \multirow{2}{*}{ No $(n=18)$} & $59.8(11.3)$ & 22.2 & $281(107)$ \\
\hline & $P=0.04$ & & $P=0.53$ \\
\hline \multicolumn{4}{|l|}{ Usual frequency of mølje consumption } \\
\hline 3 times per season or less $(n=16)$ & $60.7(14.4)$ & 25.0 & $262(96)$ \\
\hline $2-3$ times per month or more $(n=9)$ & $69.9(15.1)$ & 11.1 & $317(102)$ \\
\hline $1-3$ times per week $(n=5)$ & 77.7 (21.7) & 0.0 & $263(47)$ \\
\hline & $P=0.04 \S$ & & $P=0.64 \S$ \\
\hline \multicolumn{4}{|l|}{ Time spent in daylight $\left(\mathrm{h} \mathrm{week}^{-1}\right.$ ) } \\
\hline$<7(n=7)$ & $53.8(10.6)$ & 28.6 & $261(110)$ \\
\hline$\geq 7(n=21)$ & $72.4(16.1)$ & 4.8 & $292(89)$ \\
\hline & $P=0.02$ & & $P=0.46$ \\
\hline \multicolumn{4}{|l|}{ Vitamin D intake $\left(\mu \mathrm{g} \mathrm{day}^{-1}\right)$} \\
\hline$<10(n=16)$ & $62.4(13.4)$ & 18.8 & $245(97)$ \\
\hline \multirow[t]{2}{*}{$\geq 10(n=16)$} & $70.6(18.7)$ & 12.5 & $299(85)$ \\
\hline & $P=0.23$ & & $P=0.11$ \\
\hline
\end{tabular}

25(OH)D - 25-hydroxyvitamin D; SD - standard deviation; BMI - body mass index.

${ }^{*}$ All subgroups may not have $n=32$ due to missing values or exclusions.

† Subjects who reported that they had been on a sun holiday or used a solarium during the month prior to the study $(n=4)$ were excluded. $\ddagger$ Statistical test: Student $t$-test for comparison of means.

$\S$ Test for trend.

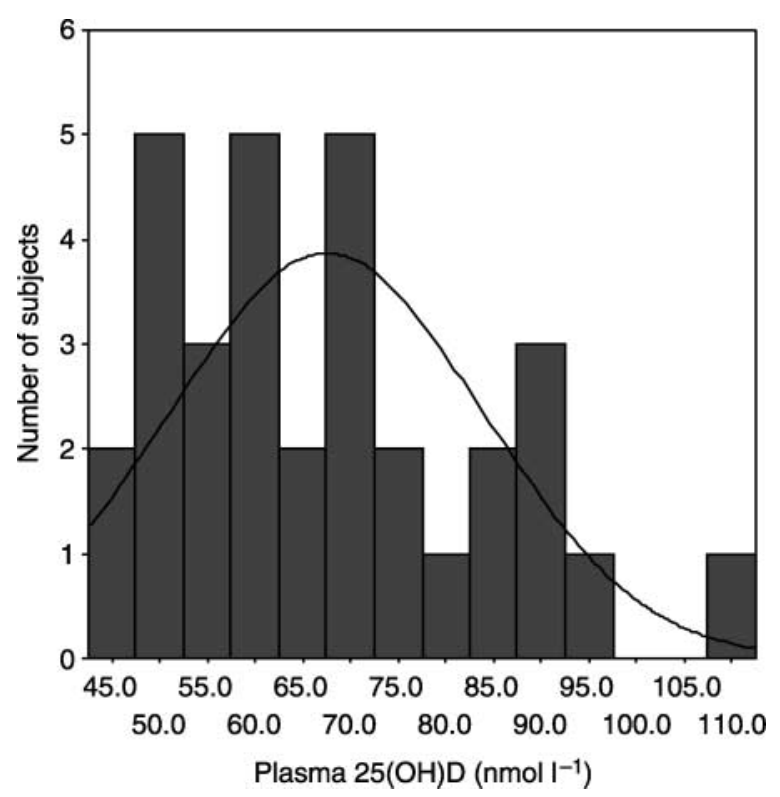

Fig. 3 Distribution of baseline plasma 25-hydroxyvitamin D $(25(\mathrm{OH}) \mathrm{D})$ concentrations among the study participants $(n=32)$ below the recommended level $\left(50 \mathrm{nmoll}^{-1}\right)$, and one quarter of the subjects were below the limit for moderate hypovitaminosis $\mathrm{D}\left(37.5 \mathrm{nmoll}^{-1}\right)$. The relatively high concentrations found in the present study compared with the Troms $\varnothing$ group suggests that the regular consumption of traditional marine food plays an important role in vitamin D status.

The recommended daily dietary intake of vitamin $\mathrm{D}$ in the Nordic countries has been set at $5 \mu \mathrm{g}^{7}$. The median self-reported vitamin D intake in the Skjervøy group was more than twice that found in nation-wide surveys conducted in Norway, ${ }^{5,18}$. Moreover, it is known that significantly higher vitamin D intake occurs in northern Norway compared with populations in the more southern parts of the country ${ }^{19}$. By comparing the relative importance of UV-induced and dietary vitamin $\mathrm{D}$ on vitamin D status, a recent study has shown that diet is the major vitamin D source during winter until late spring for northern Norwegian populations ${ }^{4}$. The study in the late 1920 s by Kloster $^{3}$ concluded that cod liver and cod-liver oil were the most important vitamin D sources for the costal population, and that rickets was common in places where 
Table 4 Multiple linear regression analysis identifying predictors for baseline $\log 25(\mathrm{OH}) \mathrm{D}(n=26)^{\star} \dagger$

\begin{tabular}{lcc}
\hline Variable & $t$-value & $P$-value \\
\hline $\begin{array}{l}\text { Cod-liver oil supplement use } \\
\quad \text { Yes }(n=14)\end{array}$ & ref. & \\
$\quad$ No $(n=18)$ & 1.47 & 0.16 \\
Usual frequency of molje consumption & & \\
3 times per season or less $(n=16)$ & ref. & \\
$2-3$ times per month or more $(n=9)$ & 1.06 & 0.30 \\
$1-3$ times per week $(n=5)$ & 2.14 & 0.05 \\
Time spent in daylight $\left(\mathrm{h} \mathrm{week}^{-1}\right)$ & & \\
$\quad<7(n=7)$ & ref. & \\
$\quad \geq 7(n=21)$ & 2.11 & 0.05 \\
$R_{\text {adj }}^{2}$ & & 0.51 \\
$P$-value for model & & 0.04 \\
\hline
\end{tabular}

25(OH)D - 25-hydroxyvitamin D; ref. - reference category.

* Subjects who reported that they had been on a sun holiday or used a solarium during the month prior to the study were excluded.

$\dagger$ Adjusted for age and gender.

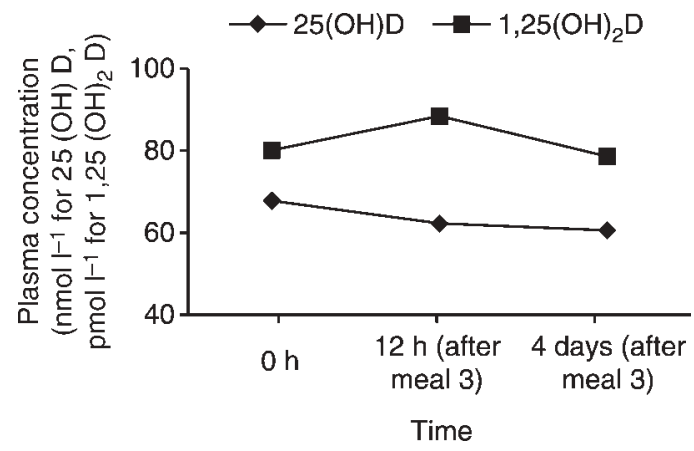

Fig. 4 Plasma concentrations of 25-hydroxyvitamin $\mathrm{D}(25(\mathrm{OH}) \mathrm{D})$ and 1,25-dihydroxyvitamin $\mathrm{D}\left(1,25(\mathrm{OH})_{2} \mathrm{D}\right)$ by time among the study participants $(n=32)$

there was limited access to fresh fish. Our results show that high consumption of mølje meals results in a satisfactory vitamin D status even when measured just after the end of the 'vitamin D winter'. This suggests that this traditional food compensates for the absence of sufficient sunlightinduced vitamin $\mathrm{D}$ production.

The finding that blood $25(\mathrm{OH}) \mathrm{D}$ level was not adequately explained by the estimate of total vitamin D intake, but by the frequency of mølje consumption, might be explained by a lower occurrence of misclassification on the mølje question as compared with the other dietary intake questions. Non-differential misclassification will dilute a true association. It has been shown previously, among subjects in northern Norway, that consumption of mølje is associated with vitamin D status ${ }^{4}$. In the abovementioned study conducted in Troms $\varnothing^{6}$, one meal of mølje increased the $25(\mathrm{OH}) \mathrm{D}$ level only for subjects with moderate hypovitaminosis $\mathrm{D}\left(25(\mathrm{OH}) \mathrm{D} \leq 37.5 \mathrm{nmoll}^{-1}\right)$. Thus, the relatively high baseline levels in the Skjervøy group could be one explanation for our finding that three mølje meals were not sufficient to raise the $25(\mathrm{OH}) \mathrm{D}$ concentration.

The increase in $1,25(\mathrm{OH})_{2} \mathrm{D}$ could be attributed to the short-time increase in PTH, which activates hydroxylation of $25(\mathrm{OH}) \mathrm{D}$ in the kidneys ${ }^{1}$. The observed increase in PTH was, however, not significant. This inability to detect a change was most likely a consequence of low statistical power (small sample size). The observed increase in active vitamin D could also be due to the metabolite being bound to fat in circulation and thereby inactivated, thus causing a need to produce more $1,25(\mathrm{OH})_{2} \mathrm{D}$.

BMI has been shown to be associated with 25(OH)D levels in blood ${ }^{6,20-22}$. This was not found in our study, probably because of the narrow range in the BMI values, as most of the subjects were overweight. The results were, however, in accordance with the mølje study conducted in Troms $\varnothing^{6}$, where there also was a short-term reduction in $25(\mathrm{OH}) \mathrm{D}$ after a mølje meal among the overweight subjects.

Lack of statistical power due to a small number of participants was a problem in the current study. Thus, substantial differences in 25(OH)D level such as those reported in Table 3 were found not to be significant. Neither was the study sample randomly selected, as the subjects were recruited based on their own willingness and initiative to participate. However, the participants' self-reported frequency of mølje consumption was in line with unpublished NOWAC data obtained in the municipality of Skjervøy and the recalled cod-liver oil supplement use in the present study was close to the prevalence found in nation-wide Norwegian ${ }^{13}$ and northern Norwegian studies ${ }^{4,22}$. Since the study objective was to investigate the impact of mølje on vitamin D status in a high consumption group living in a rural area of northern Norway, the external validity of the findings is of less importance.

In conclusion, cod liver and fresh cod-liver oil can constitute a good vitamin D source. Three consecutive mølje meals on average provided 54 times the recommended daily dose of vitamin D. Subjects with food habits that include frequent mølje meals during the winter can sustain satisfactory vitamin D levels in their blood, despite the lack of UV-induced vitamin D production.

\section{Acknowledgements}

The authors would like to acknowledge the volunteers at Skjervøy for their enthusiasm and goodwill. Furthermore, the effort and dedication by staff and students of the Skjervøy Upper Secondary School, in particular headmaster Ronny Laberg, were essential for the success of this project. We are grateful to the staff at Skjervøy Health Centre for offering their time and making their facilities at our disposal. We would also acknowledge Guri Skeie (Institute of Community Medicine, University of Troms $\varnothing$ ) for participating in the data collection and conducting the nutrient calculations, Elin Albrigtsen (Institute of Community Medicine, University of Troms $\varnothing$ ) for collecting the blood specimens and Professor Evert Nieboer (McMaster University, Hamilton, Ontario, Canada) for editing the manuscript. 


\section{References}

1 Holick MF. Vitamin D. In: Shils M, Olson JA, Shike M, eds. Modern Nutrition in Health and Disease. Malvern, PA: Lea \& Febiger, 1994; 308-25.

2 Webb AR, Kline L, Holick MF. Influence of season and latitude on the cutaneous synthesis of vitamin $\mathrm{D}_{3}$ : exposure to winter sunlight in Boston and Edmonton will not promote vitamin $\mathrm{D}_{3}$ synthesis in human skin. Journal of Clinical Endocrinology and Metabolism 1988; 67(2): 373-8.

3 Kloster J. The distribution and frequency of rickets in one of the fishery districts of Finnmark and relation of diet to the disorder. Acta Paediatrica 1931; 12(Suppl. 3): 1-82.

4 Brustad M, Alsaker E, Engelsen O, Aksnes L, Lund E. Vitamin D status of middle-aged women at $65-71^{\circ} \mathrm{N}$ in relation to dietary intake and exposure to ultraviolet radiation. Public Health Nutrition 2004; 7(2): 327-35.

5 Hjartaker A, Lund E. Relationship between dietary habits, age, lifestyle, and socio-economic status among adult Norwegian women. The Norwegian Women and Cancer Study. European Journal of Clinical Nutrition 1998; 52(8): $565-72$.

6 Brustad M, Sandanger T, Wilsgaard T, Aksnes L, Lund E. Change in plasma levels of vitamin $\mathrm{D}$ after consumption of cod liver and fresh cod-liver oil as part of the traditional north Norwegian fish dish 'Mølje'. International Journal of Circumpolar Health 2003; 62(1): 40-53.

7 Sandström B, Aro A, Becker W, Lyhne N, Pedersen JI, Pórsdóttir I. Nordiska näringsrekommendationer 1996 [Nordic Nutrient Recommendations], 1st ed. Copenhagen: Nordiska Ministerrådet, 1996.

8 Holick MF. The use and interpretation of assays for vitamin D and its metabolites. Journal of Nutrition 1990; 120(Suppl. 1): S1464-9.

9 Lehtonen VM, Mottonen T, Irjala K, Karkkainen M, Lamberg AC, Hakola P, et al. Vitamin D intake is low and hypovitaminosis D common in healthy 9- to 15-year-old Finnish girls. European Journal of Clinical Nutrition 1999; 53(9): 746-51.

10 Thomas MK, Lloyd JD, Thadhani RI, Shaw AC, Deraska DJ, Kitch BT, et al. Hypovitaminosis D in medical inpatients. New England Journal of Medicine 1998; 338(12): 777-83.

11 Malabanan A, Veronikis IE, Holick MF. Redefining vitamin D insufficiency. Lancet 1998; 351(9105): 805-6.
12 Schmidt-Gayk H, Bouillon R, Roth HJ. Measurement of vitamin D and its metabolites (calcidiol and calcitriol) and their clinical significance. Scandinavian Journal of Clinical and Laboratory Investigation. Supplementum 1997; 227: $35-45$.

13 Brustad M, Braaten T, Lund E. Predictors for cod-liver oil supplements use - the Norwegian Women and Cancer Study. European Journal of Clinical Nutrition 2004; 58 : 128-36.

14 Rimestad AH, Borgejordet A, Vesterhus KN, Sygnestveit K, Løken EB, Trygg K, et al. Den store matvaretabellen [The Great Food Composition Table], 2nd ed. Oslo: Gyldendal, 2001.

15 Horvli $\mathrm{O}$, Lie $\varnothing$. Determination of vitamin $\mathrm{D}_{3}$ by HPLC. Norwegian Fishery Directorate Report on Nutrition 1994; 6(2): $163-75$.

16 Aksnes L. Quantitation of the main metabolites of vitamin D in a single serum sample. II. Determination by UVabsorption and competitive protein binding assays. Clinica Chimica Acta 1980; 104(2): 147-59.

17 Aksnes L. Quantitation of the main metabolites of vitamin D in a single serum sample. I. Extraction, separation and purification of metabolites. Clinica Chimica Acta 1980; 104(2): 133-46.

18 Johansson L, Solvoll K, Bjørneboe G-EA, Drevon CA. Dietary habits among Norwegian men and women. Scandinavian Journal of Nutrition/Näringsforskning 1997; 41: 63-70.

19 Johansson L, Solvoll K. Norkost 1997 - Landsomfattende kostholdsundersøkelse blant menn og kvinner i alderen 1679 år [Nationwide Dietary Survey among Men and Women ages 16-79]. Oslo: Statens råd for ernæring og fysisk aktivitet, 1999.

20 Need AG, Morris HA, Horowitz M, Nordin C. Effects of skin thickness, age, body fat, and sunlight on serum 25hydroxyvitamin D. American Journal of Clinical Nutrition 1993; 58(6): $882-5$.

21 Wortsman J, Matsuoka LY, Chen TC, Lu Z, Holick MF. Decreased bioavailability of vitamin D in obesity. American Journal of Clinical Nutrition 2000; 72(3): 690-3.

22 Hjartaker A, Lund E, Bjerve KS. Serum phospholipid fatty acid composition and habitual intake of marine foods registered by a semi-quantitative food frequency questionnaire. European Journal of Clinical Nutrition 1997; 51(11): $736-42$. 